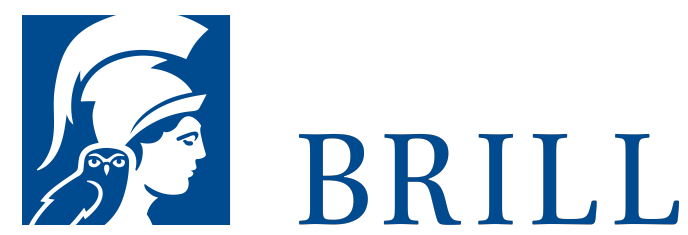

\title{
Hans-Dietrich Genscher
}

Die Biographie

\section{Author: Hans-Dieter Heumann}

Seit der Gründung des Auswärtigen Amtes 1871 gab es keinen, der ihm länger gedient hat als HansDietrich Genscher. Er prägte eine 18jährige Ära (19741992), die von dem Konflikt und der Entspannung zwischen West und Ost über das Ende des Kalten Krieges und die Vereinigung Deutschlands bis zu den Kriegen am Golf und auf dem Balkan reichte.

Auf der Grundlage vieler Gespräche mit HansDietrich Genscher, Interviews mit prominenten Zeitzeugen und der Öffentlichkeit nicht zugänglichen Dokumenten des Politischen Archivs im AA hat HansDieter Heumann die erste Biographie des angesehensten deutschen Außenministers vorgelegt. Ebenso kenntnisreich wie einfühlsam zeichnet er ein Bild des Menschen HansDietrich Genscher, indem er seine Herkunft und Prägungen schildert und seinen tieferen Triebkräften und Eigenschaften nachspürt. Ausgewogen und nicht ohne kritische Distanz würdigt er die Herausforderungen und Leistungen Genschers auf der weltpolitischen Bühne.

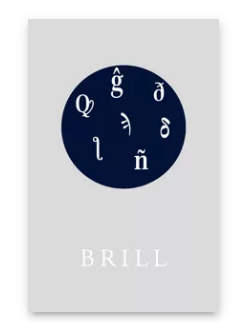

Pages: 346 Seiten

Language:

German

Subjects:

Contemporary

History, History

Publisher: Brill |

Schöningh

E-Book (PDF)

Released online:

O2 Jan 2012

ISBN: $978-3^{-}$

657-77037-3 
Hans-Dieter Heumann, Dr. phil., geb. 1950, ist seit 2009 Ständiger Vertreter der Bundesrepublik Deutschland beim Europarat in Straßburg. 19651972 Studium der Musik an der Staatlichen Hochschule für Musik in Köln; 19721978 Studium der Politischen Wissenschaft in Berlin und Bonn; seit 1982 ist er in verschiedenen Funktionen im AA tätig. Er ist Commandeur de l’Ordre National du Mérite, République Française.

For more information see brill.com

Order information: Order online at brill.com +44330 333 o049 | customerservices@brill.com Submission information: brill.com/authors

Titles published by Brill | Fink, Brill | mentis or Brill | Schöningh: +49(o)71 5413279216 | brill@brocom.de 